\title{
Estimation of Tropical Forest Structural Characteristics Using ALOS-2 SAR Data
}

\author{
Luong Viet Nguyen ${ }^{1,2}$, Ryutaro Tateishi' ${ }^{1}$, Hoan Thanh Nguyen ${ }^{3}$, Ram C. Sharma ${ }^{1}$, \\ Tu Trong To'2, Son Mai Le ${ }^{2}$ \\ ${ }^{1}$ Center for Environmental Remote Sensing, Chiba University, Chiba, Japan \\ ${ }^{2}$ Space Technology Institute, Vietnam Academy of Science and Technology, Hanoi, Vietnam \\ ${ }^{3}$ Institute of Geography, Vietnam Academy of Science and Technology, Hanoi, Vietnam \\ Email: nvluong@sti.vast.vn
}

Received 28 April 2016; accepted 24 June 2016; published 27 June 2016

Copyright (C) 2016 by authors and Scientific Research Publishing Inc.

This work is licensed under the Creative Commons Attribution International License (CC BY).

http://creativecommons.org/licenses/by/4.0/

(c) () Open Access

\section{Abstract}

The potential of ALOS-2 SAR data for the estimation of tropical forest structural characteristics was assessed in Vietnam by collecting forest inventory data. The effect of polarization and seasonality of the SAR data on the estimation of forest biomass was analyzed. The combination of $\mathrm{HH}$, $\mathrm{HV}$, and $\mathrm{HH} / \mathrm{HV}$ polarizations using multiple linear regression did not improve the estimation of biomass compared to using the $\mathrm{HV}$ channel independently, as the $\mathrm{HH}$ and $\mathrm{HH} / \mathrm{HV}$ variables were not statistically significant. The dry season HV backscattering intensity was highly sensitive to the biomass compared to the rainy season backscattering intensity. The SAR data acquired in the rainy season with humid and wet canopies was not very sensitive to the biomass. The strong dependence of the biomass estimates with the season of SAR data acquisition confirmed that the choice of right season SAR data is very important for improving the satellite based estimates of the biomass. The validation results showed that the dry season HV polarization could explain $54 \%$ variation of the biomass.

\section{Keywords}

Forest Structure, Forest Biomass, SAR, ALOS-2, Backscattering Intensity, Sensitivity Analysis

\section{Introduction}

Forest biomass plays an important role in global carbon cycle [1]-[3]. However, global forest area has decreased by about 5.3 million hectares per year between 1999 and 2010; and deforestation is continuing everywhere [4][7]. Accurate monitoring of forest biomass and $\mathrm{CO}_{2}$ sequestration rates are immensely important for increasing

How to cite this paper: Nguyen, L.V., Tateishi, R., Nguyen, H.T., Sharma, R.C., To, T.T. and Le, S.M. (2016) Estimation of Tropical Forest Structural Characteristics Using ALOS-2 SAR Data. Advances in Remote Sensing, 5, 131-144. 
understanding of carbon cycles, improving climate change forecasting models, and climate change mitigation and adaptation strategies [3] [8] [9]. Monitoring of forest carbon is also necessary for the United Nation's program on Reducing Emissions from Deforestation and Degradation (REDD+), a financial payment mechanism for environmental services [8] [10].

Satellite remote sensing has been widely used for estimation of biomass. However, optical data saturates over high biomass regions, and detection of vertical structure is difficult [3] [11]-[14]. Therefore, multi-angular remote sensing based bi-directional reflectance data have been tried for improving the retrieval of canopy structural information [15] [16]. At a local scale, lidar sensors have provided better estimates of biomass and woody volume by directly measuring the structure of forest [12] [17]-[25]. Synthetic Aperture Radar (SAR) data has high potential for the estimation of forest structural parameters because long-wavelength radar signals can penetrate into forest canopy, and it is unaffected by clouds, and day or night [3] [26]-[37]. The major techniques for SAR based estimates of biomass are regression modelling [28] [38]-[40], dual-wavelength SAR interferometry [41]; image texture analysis [42]; random volume over ground model [35], water cloud model [43], combination of forest structure and radiative transfer models [36], and electromagnetic modelling [44].

SAR data have been used for estimation of biomass from local to regional/country level such as pine plantation in Southwest Alabama [27], Mount Sharsta region of Northern California [45], plantation forest of the Landes forest in southwestern France [28], Brazilian Amazon [30] [37], Nuuksio Natural Park in Southern Finland [46], Queensland in Australia [47], Mozambique in Zambézia province [40], Cameroon [44] and Japan [48] as some examples. However, backscattering mechanism in forests is very complex due to multi-level interaction of the scatterings with several horizontal and vertical components of trees. It is also affected by the environmental conditions. Different kinds of backscattering phenomena in forests such as diffused scattering from the ground, direct scattering from thin and dense vegetation parts, double bounce vegetation-ground interaction, direct backscattering from the canopy, volume scattering from within the forest canopy, and shadowing have been reported [26] [49]-[53]. Backscattering intensity is also affected by a number of site conditions such as environmental temperatures [54] [55], textures [56], moistures [57]-[62], roughness [57] [59] [63] [64], terrain slopes [39] [44] [64] [65], forest species and cover [52] [66] [67], and forest stand age and canopy structure [48] [42] [68].

The previous SAR based biomass models established especially at a large area have usually used the SAR data without considering the season of the year when the satellite data was acquired. As a result, there are uncertainties on the application of these models into new forest areas. Therefore, this research was conducted in a tropical forest to assess the uncertainties associated with the estimation of biomass by collecting in situ forest data. This research attempted to answer whether the ALOS-2 based SAR data are really capable of estimating forest structure and biomass in high biomass regions, and whether biomass estimates vary with the season and polarization of SAR data.

The paper is organized as follows: Sections 2 and 3 describe the study area and data used. The procedure on in situ forest measurements, and SAR data based analysis of forest structure is explained in Section 4. Section 5 presents results on polarization and seasonal effects of the SAR data on the estimation of forest structures.

\section{Study Area}

This research was carried out in Yok Don National Park, the largest national park in Vietnam which is located in the Central Highlands region. This park is very rich in biodiversity where 474 vascular plant species have been recorded [69]. This park is one of the most important protected area in Southeast Asia providing important habitat for conservation of globally endangered species such as Indochinese tiger and Asian elephant.

This park has two major types of forest: deciduous broadleaf forest and evergreen broadleaf forest [69]-[73]. The dominant tree species in the deciduous broadleaf forest are Dipterocarpus tuberculatus, Dipterocarpus obtusifolius, Terminalia tomentosa, and Shorea obtuse. The evergreen broadleaf forest mainly comprises of Michelia mediocris, Cinamomum iners, Syzygium zeylanicum, Syzygium wightianum, Garruga pierrei, Gonocaryum lobbianum, Schima superba, Camellia assamica, and Lithocarpus fenestratus. The forest inside the park has diverse types of soils including brown, red-yellow, and black soils [74]. This park contains relatively plain topography and is located at an altitude of $200-300 \mathrm{~m}$ above sea level [75]. The location map of the Yok Don National Park is shown in Figure 1.

The climate of this region is tropical monsoon type which has a well-defined dry season between October and 


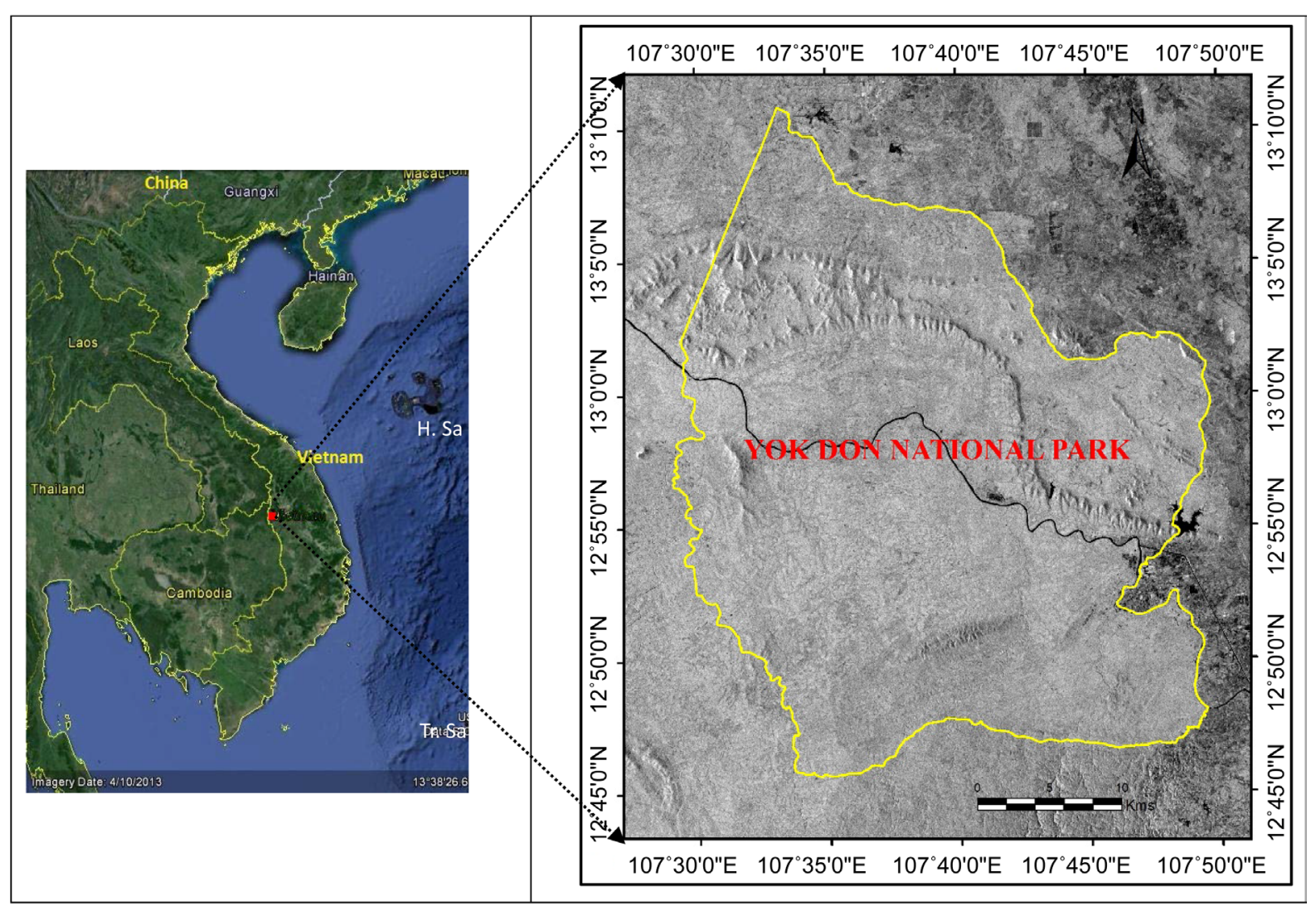

Figure 1. Location map of the study area displaying the boundary of Yok Don National Park (yellow polygon) in Central Highlands region, Vietnam.

April, and typical rainy season between May and November. The mean annual rainfall is $1540 \mathrm{~mm}$, and mean monthly temperature is around $25^{\circ} \mathrm{C}$. The well-defined distinction of the climate between the dry and rainy seasons found in this forest provides an ideal site to analyze how the backscattering intensity varies with the seasons, and to know how the seasonal variation of the backscattering intensity affects the estimation of biomass. Moreover, this forest with dense and multi-strata canopies consisting of diverse tree species in tropical monsoon setting provides an opportunity to analyze how the backscattering intensity is sensitive to large biomass. The analysis on sensitivity of backscattering intensity is required for improving the SAR based estimates of the biomass particularly in the dense and multi-strata tropical rain forests.

\section{Acquisition and Processing of ALOS-2 SAR Data}

We used synthetic aperture radar (SAR) data from ALOS-2 satellite which has been operating since May 2014 and provides SAR data in L-band. We used ALOS-2 version 2.1 polarized SAR data in HH and HV polarizations with pixel resolution of $6.25 \mathrm{~m}$ and it was available as a geometrically corrected product. The digital number (DN) values of the SAR images in both the HH and HV polarizations were calibrated by calculating the backscattering intensity using the Equation (1) [76].

$$
\sigma^{\mathrm{o}}=10 \times \log 10\left(\mathrm{DN}^{2}\right)+\mathrm{CF}
$$

In Equation (1), the $\sigma^{0}$ is the sigma-naught backscattering intensity in the units of decibels $(\mathrm{dB})$, and $\mathrm{CF}$ is the calibration factor which is currently set as -83 [76]. We used two scenes of the ALOS-2 data covering our study area and representing each of the rainy (October) and dry season (February).

The precipitation condition of the study area is shown in Table 1. As shown in the table, the rainy 3 months received mean of $190.2 \mathrm{~mm}$ rainfall whereas the dry 3 months received absolutely no rainfall [77].

The description of ALOS-2 SAR data used in the research are shown in Table 2. Both dry and rainy season 
Table 1. Summary of the precipitation condition of the study area.

\begin{tabular}{ccccccc}
\hline Year & \multicolumn{2}{c}{$\mathbf{2 0 1 4}$} & \multicolumn{2}{c}{$\mathbf{2 0 1 5}$} \\
\hline Months & Aug. & Sept. & Oct. & Jan. & Feb. & Mar. \\
\hline Total rainfall (mm) & 170.8 & 204.7 & 195.3 & 0 & 0 & 0 \\
Max. rainfall per day (mm) & 53.0 & 59.5 & 35.5 & 0 & 0 & 0 \\
Min. rainfall per day (mm) & 1.0 & 1.0 & 1.0 & 0 & 0 & 0 \\
Total number of rainy days & 14 & 16 & 14 & 0 & 0 & 0 \\
\hline
\end{tabular}

Table 2. Description of the ALOS-2 PALSAR-2 data used in this research.

\begin{tabular}{cccccc}
\hline No. & Observation date (time) & Scene ID & Polarizations & Obs. angle & Seasons \\
\hline 1 & $2014-10-05(16: 56: 51)$ & ALOS2019900240-141005-FBDR2.1GUA & HH, HV & $32.9^{\circ}$ & Rainy \\
2 & $2014-10-05(16: 56: 51)$ & ALOS2019900250-141005-FBDR2.1GUA & HH, HV & $32.9^{\circ}$ & Rainy \\
3 & $2015-02-22(16: 56: 50)$ & ALOS2040600240-150222-FBDR2.1GUA & HH, HV & $32.9^{\circ}$ & Dry \\
4 & $2015-02-22(16: 56: 50)$ & ALOS2040600250-150222-FBDR2.1GUA & HH, HV & $32.9^{\circ}$ & Dry \\
\hline
\end{tabular}

SAR images acquired with the same off-nadir angle $\left(32.9^{\circ}\right)$ in descending modes were used in order to avoid bias related to observation angles.

\section{Methodologies}

\subsection{In Situ Measurements}

Field measurements were conducted in April, 2015 by establishing sample plots according to the inventory guideline available for the Central Highlands region of Vietnam [78] [79]. Altogether, 110 sample plots were established by meeting a criteria of representativeness of different forest types across the study areas. The authors carefully designed the sample plots in such a way that they were at least 100-m apart from trails, roads, streams, and rivers to avoid the signals from unwanted surface types for sensitivity analysis.

Each sample plot established during the forest inventory was $(100 \mathrm{~m} \times 100 \mathrm{~m})$ with an area of 1 ha. The diameter at breast height (D) and total tree height $(\mathrm{H})$ of all the trees larger than $5 \mathrm{~cm}$ diameter at breast height located inside the sample plots were measured. The tree diameter and height were measured by using laser diameter and laser height instruments respectively. The central geo-location (latitude and longitude) of each sample plot was also recorded by using GPS instrument. The taxonomy of tree species was also recorded during the field inventory following the Vietnam Flora book [80]. The sample plots represent 110 hectares forest area which is nearly $0.1 \%$ of the total study area.

The distribution of sample plots used in this research are shown in Figure 2 using RGB color composite of the SAR images. Distinct variation between the rainy season and dry season RGB images in Yok Don National Park were observed as demonstrated in Figure 2.

\subsection{Calculation of Forest Structural Parameters}

The individual tree data: diameter at breast height $(\mathrm{D})$ and total tree height $(\mathrm{H})$ were used to calculate above ground biomass (AGB) using the allometric equations. We used separate allometric equations for calculating the AGB of the deciduous and evergreen forests [79]. The allometric equations used for calculating the AGB of deciduous and evergreen forest types are given in Equation (2) and Equation (3) respectively.

$$
\begin{gathered}
\mathrm{AGB}=0.14 \times \mathrm{D}^{2.31} \\
\mathrm{AGB}=0.098 \times \exp (2.08 \times \operatorname{Ln}(\mathrm{D})+0.71 \times \operatorname{Ln}(\mathrm{H})+1.12 \times \operatorname{Ln}(\mathrm{WD}))
\end{gathered}
$$




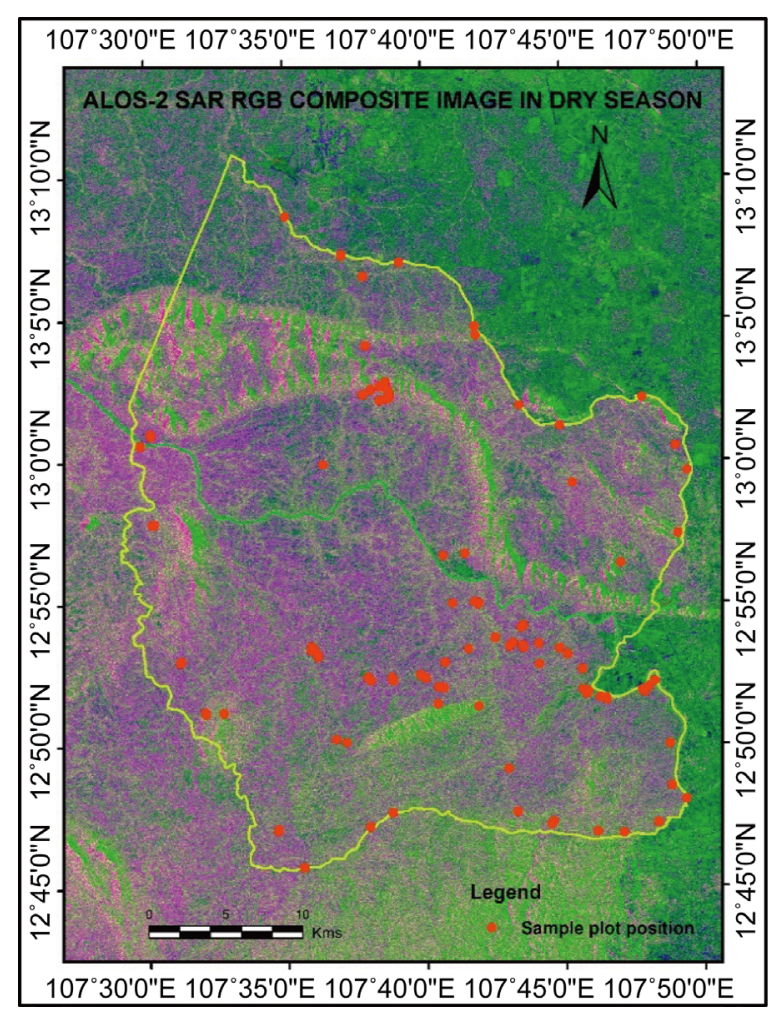

(a)

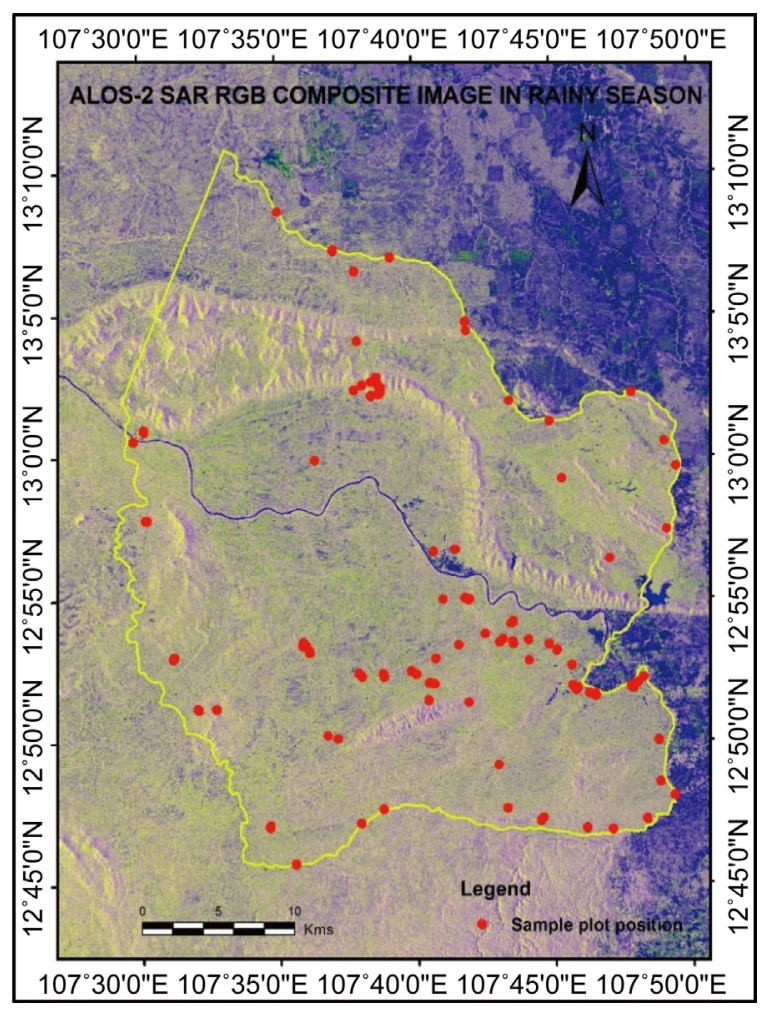

(b)

Figure 2. The distribution of the location of sample plots established during field survey over the RGB color composite images: (a) Dry season RGB image, and (b) Rainy season RGB image. The RGB color composite image was created by using the HH channel for red (R), HV channel for green (G), and the ratio HH/HV for blue (B).

In Equations (2)-(3), AGB is the above ground biomass of a tree in kilograms (kg); D is the diameter at breast height measured at 1.3-m above the ground level in meters (m); $\mathrm{H}$ is the total height of tree in meters (m); WD is the wood density of tree in tones dry matter per fresh cubic meters $\left(\operatorname{ton} / \mathrm{m}^{3}\right)$. The species-specific wood density (WD) data were obtained from the forest carbon measurement guidelines prepared by the IPCC [81]. The species-specific wood density data were used for calculating the AGB in evergreen forests due to large number of tree species present in these forests with varying amount of AGB. The allometric equations of the AGB in Equation (2) and Equation (3) gives total biomass of a tree including all the stems, branches and leaves.

\subsection{Sensitivity Analysis}

Averages of the forest structural parameters: basal area (BA), tree height (H), and above ground biomass (AGB) were calculated per each sample plot. The sample plots represent larger variation of the diameter at breast height (8.1 - $48.4 \mathrm{~cm}$ ), tree height $(6.3-18.2 \mathrm{~m})$, and biomass $\left(42-350 \mathrm{Mg} \cdot \mathrm{ha}^{-1}\right)$. For each plot, mean backscattering intensity of $\mathrm{HH}$ and HV polarization data were calculated using $16 \times 16$ pixels equivalent to $100 \mathrm{~m} \times 100 \mathrm{~m}$ plot size. Then the relationship between forest structural parameters and backscattering intensity was analyzed by randomly selecting 55 sample plots for training and 55 sample plots for validation. The sensitivity of the backscattering intensity to the biomass was statistically analyzed by using simple linear regression and multiple linear regression analysis. The coefficient of determination $\left(\mathrm{R}^{2}\right)$ in Equation (4) and root mean square error (RMSE) in Equation (5) were used as the metrics for evaluating the relationships.

$$
\begin{aligned}
& \mathrm{R}^{2}=1-\frac{\text { Explained Sum of Squares }}{\text { Total Sum of Squares }} \\
& \text { RMSE }=\sqrt{\frac{1}{n} \sum_{j=1}^{n}(\text { predicted value }- \text { observed value })^{2}}
\end{aligned}
$$




\section{Results and Discussions}

\subsection{Backscattering Intensity vs. Structural Parameters}

The sensitivity of structural parameters to the backscattering intensity of $\mathrm{HV}$ and $\mathrm{HH}$ polarizations for the dry season and rainy season was analyzed using the coefficient of determination $\left(\mathrm{R}^{2}\right)$ and root mean square error (RMSE). The results of the relationship between structural parameters and SAR data in the dry season are shown in Figure 3.

The relationship between structural parameters and SAR data in rainy season are shown in Figure 4.

The summary of the relationship between field-measured forest structural parameters and SAR data are shown in Table 3.

This analysis showed that vertical structural parameters, i.e., tree height was not closely related to the SAR data acquired in both dry and wet season than the horizontal structural parameter, i.e., basal area (BA).

\subsection{Effect of Polarization}

The sensitivity of biomass to the backscattering intensity of the HV and $\mathrm{HH}$ polarizations of the dry season was



(a)

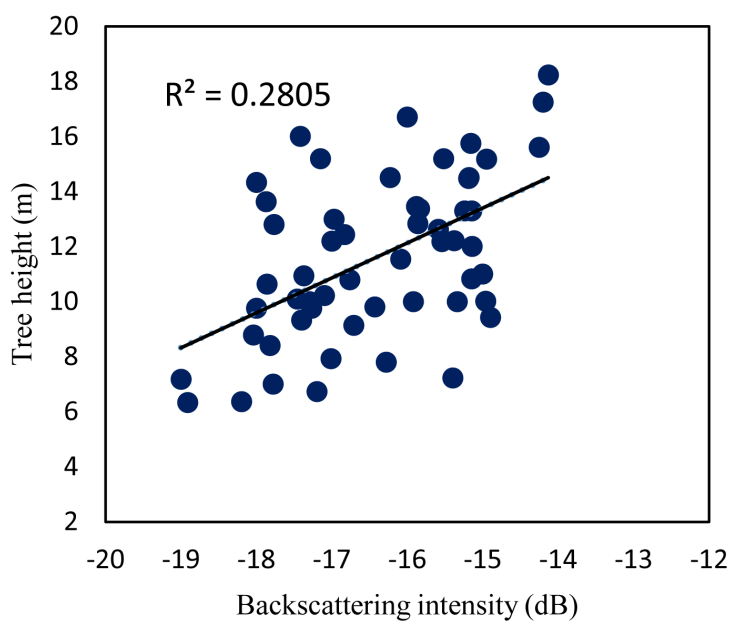

(c)

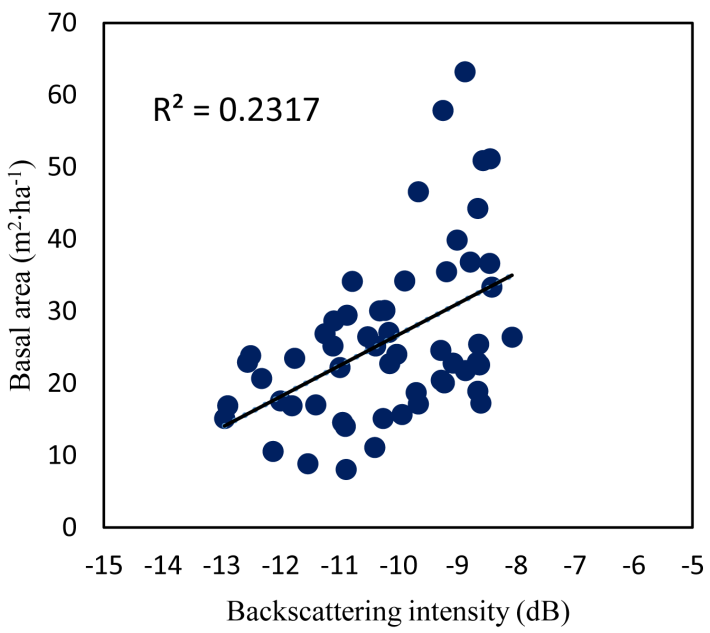

(b)

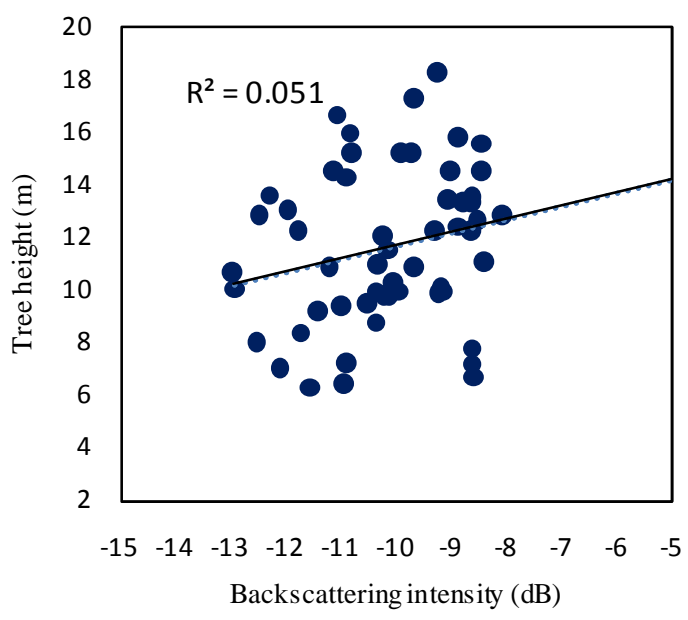

(d)

Figure 3. The relationship between structural parameters and backscattering intensity during dry season: (a) basal area and backscattering intensity (HV); (b) basal area and backscattering intensity (HH); (c) tree height and backscattering intensity (HV); (d) tree height and backscattering intensity (HH). 


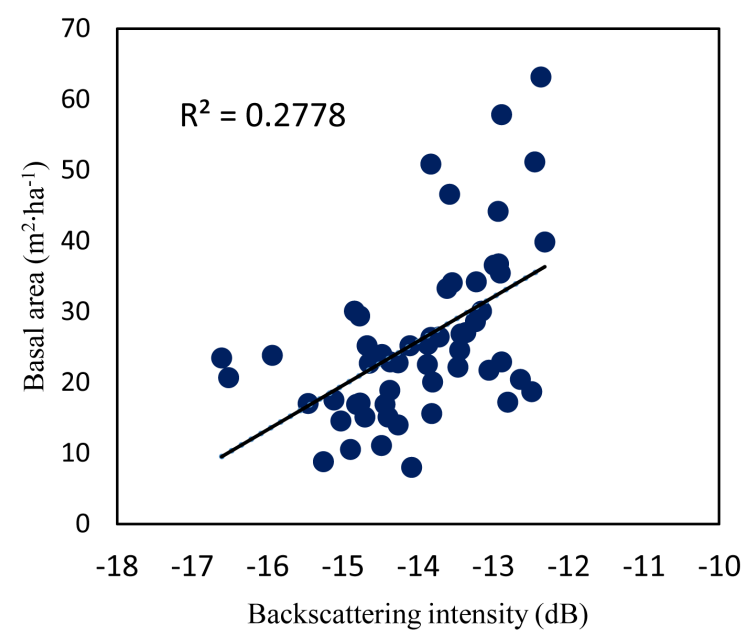

(a)

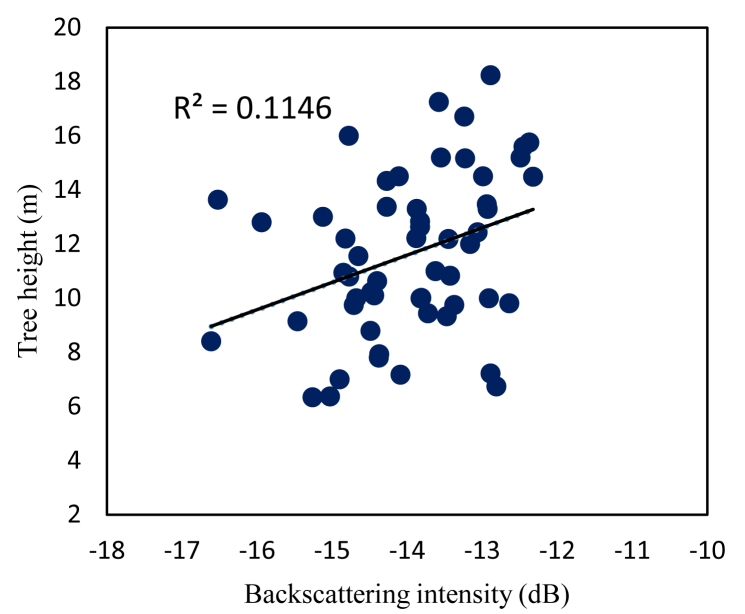

(c)



(b)

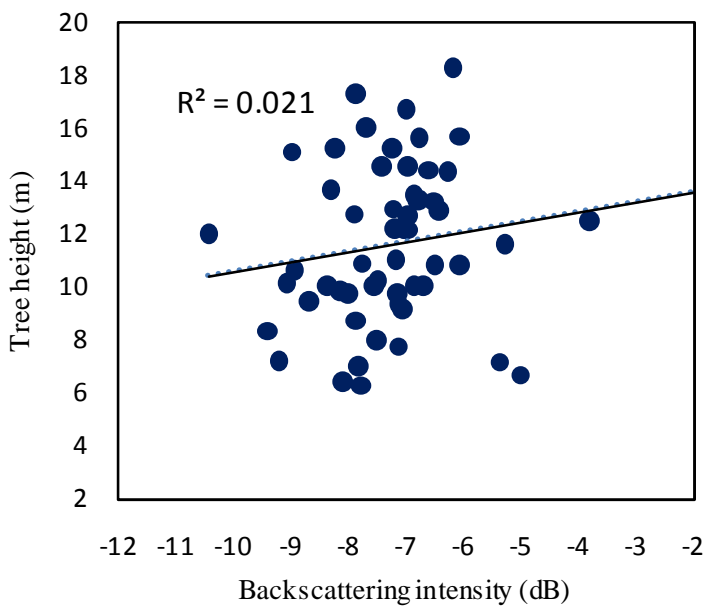

(d)

Figure 4. The relationship between structural parameters and backscattering intensity during rainy season: (a) basal area and backscattering intensity (HV); (b) basal area and backscattering intensity (HH); (c) tree height and backscattering intensity (HV); (d) tree height and backscattering intensity (HH).

Table 3. Summary of the relationship between field-measured forest structural parameters and SAR data using linear regression analysis based coefficient of determination $\left(\mathrm{R}^{2}\right)$ and root mean square error (RMSE).

\begin{tabular}{cccc}
\hline Season & Relationship & $\mathbf{R}^{2}$ & RMSE \\
\hline HV and basal area & 0.47 & 6.22 \\
HH and basal area & 0.23 & 9.13 \\
HV and tree height & 0.20 & 2.36 \\
& HH and tree height & 0.05 & 8.58 \\
HV and basal area & 0.27 & 11.3 \\
HH and basal area & 0.04 & 2.97 \\
\hline
\end{tabular}


analyzed using the coefficient of determination $\left(\mathrm{R}^{2}\right)$ and Root Mean Square Error (RMSE). As shown in Figure 5 , the HV polarization was highly related to the biomass $\left(\mathrm{R}^{2}=0.57, \mathrm{RMSE}=35.49 \mathrm{Mg} \cdot \mathrm{ha}^{-1}\right)$; whereas the HH polarization did not show a significant relationship with the above ground biomass $\left(\mathrm{R}^{2}=0.28\right.$, RMSE $=59.35$

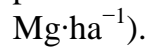

Similarly, the sensitivity of biomass to the backscattering intensity of the HV and HH polarizations for the rainy season is shown in Figure 6. The HV polarization was related to biomass $\left(R^{2}=0.34\right.$, $R M S E=54.38$ $\mathrm{Mg} \cdot \mathrm{ha}^{-1}$ ) better than the HH polarization for the biomass $\left(\mathrm{R}^{2}=0.0039\right.$, RMSE $\left.=82.59 \mathrm{Mg} \cdot \mathrm{ha}^{-1}\right)$.

The summary of the relationship between field-measured biomass and SAR data are shown in Table 4.

The high sensitivity of the HV polarization to the biomass was found for both the dry and rainy season SAR data than the HH polarization. This analysis highlighted the importance of HV polarization for the estimation of biomass.

\subsection{Effect of SAR Seasonality on Biomass}

The sensitivity of the SAR data (HV and HH polarizations) acquired during dry season and rainy season on

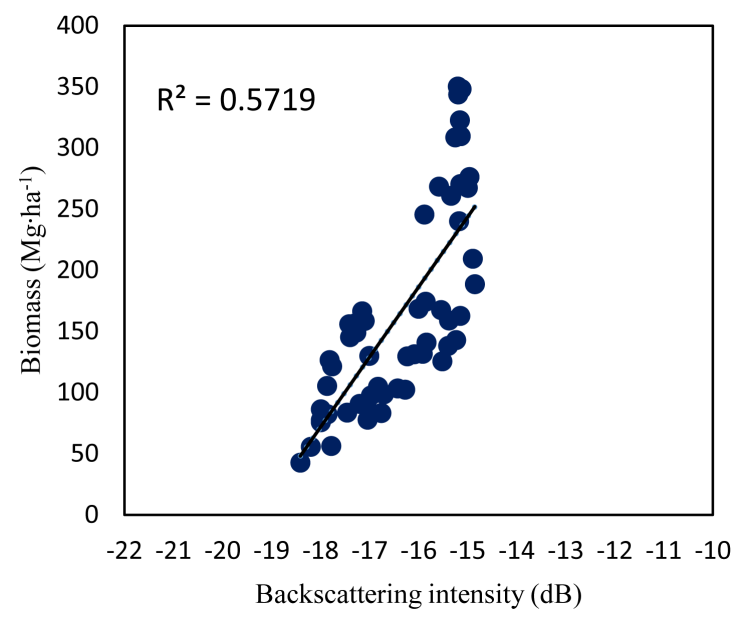

(a)

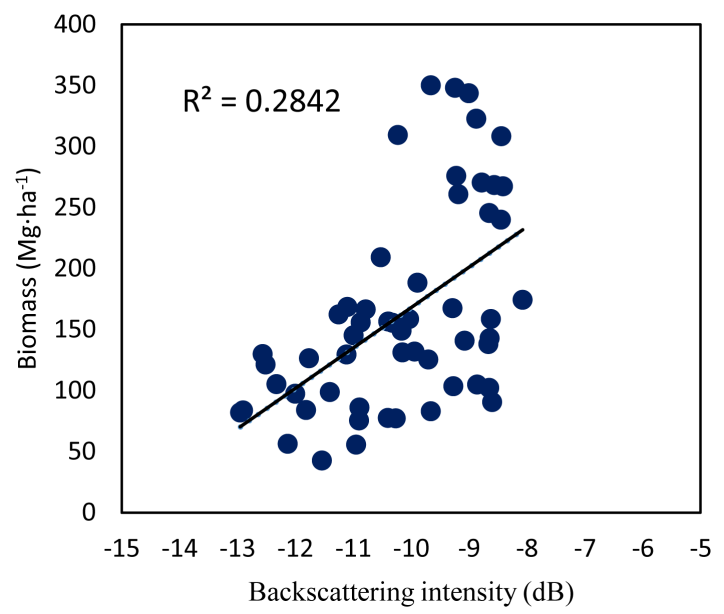

(b)

Figure 5. The relationship between biomass and backscattering intensity during dry season: (a) biomass versus backscattering intensity (HV); (b) biomass versus backscattering intensity (HH).

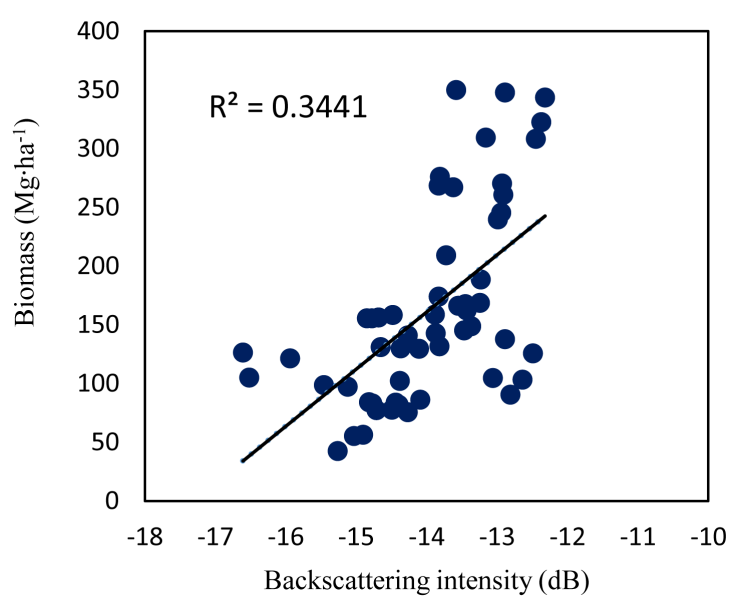

(a)

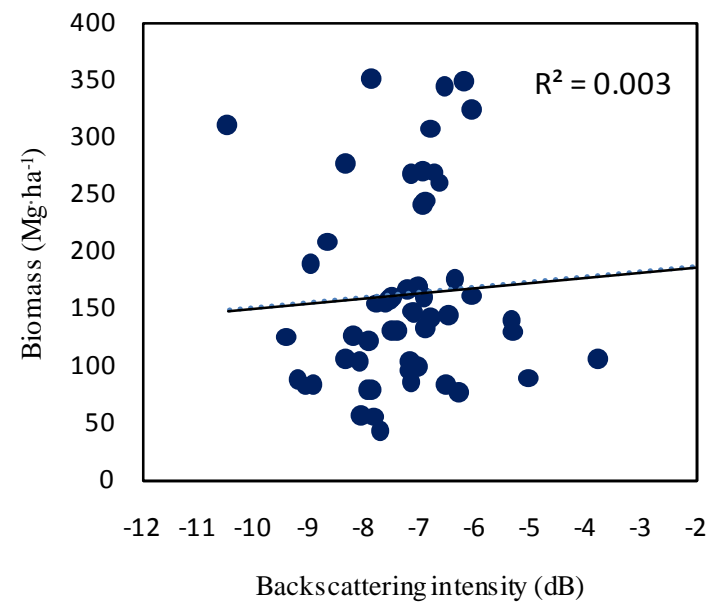

(b)

Figure 6. The relationship between the biomass and backscattering intensity during rainy season: (a) biomass versus backscattering intensity (HV); (b) biomass versus backscattering intensity (HH). 
Table 4. Summary of the relationship between field-measured biomass and SAR data using linear regression analysis based coefficient of determination $\left(\mathrm{R}^{2}\right)$ and root mean square error (RMSE).

\begin{tabular}{|c|c|c|c|}
\hline Season & Relationship & $\mathbf{R}^{2}$ & RMSE \\
\hline \multirow{2}{*}{ Dry } & HV with biomass & 0.57 & 35.49 \\
\hline & HH with biomass & 0.28 & 59.35 \\
\hline \multirow{2}{*}{ Rainy } & HV with biomass & 0.34 & 54.38 \\
\hline & HH with biomass & 0.0039 & 82.59 \\
\hline
\end{tabular}

biomass were shown in Figure 5 and Figure 6 respectively. The dry season backscattering intensity of the HH and HV polarizations was highly sensitive to the biomass than the rainy season backscattering intensity. The higher relationship between the dry season HV polarization and biomass $\left(\mathrm{R}^{2}=0.57\right.$, RMSE $\left.=35.49 \mathrm{Mg} \cdot \mathrm{ha}^{-1}\right)$ was obtained. However, the relationship between the rainy season HV polarization and biomass was relatively lower $\left(\mathrm{R}^{2}=0.34\right.$, $\left.\mathrm{RMSE}=54.38 \mathrm{Mg} \cdot \mathrm{ha}^{-1}\right)$ than the dry season. This analysis suggests that dry season SAR data is more important for estimating the biomass than the rainy season data. The effect of seasonality for the SAR data was clearly observed in this research.

We also analyzed multiple linear regression between the SAR data (HH, $\mathrm{HV}$, and $\mathrm{HH} / \mathrm{HV}$ ) and biomass using both the dry and rainy seasons SAR data. The summary of the relationship between the field-measured biomass and SAR data are shown in Table 5.

As shown in Table 5, the adjusted coefficient of determination $\left(\mathrm{R}^{2}\right)$ between the biomass and three independent variables $(\mathrm{HH}, \mathrm{HV}$, and $\mathrm{HH} / \mathrm{HV})$ was 0.58 . However the p-value of the $\mathrm{HH}$ was $0.21(>0.05)$ and $\mathrm{HH} / \mathrm{HV}$ variables was $0.19(>0.05)$ which were not significant; whereas only the HV variable with p-value $0.000(<0.05)$ was significant. Similar results were obtained for the rainy season SAR data as well. This analysis confirmed the importance of $\mathrm{HV}$ polarization mainly from the dry season.

\subsection{Validation Results}

The separate set of validation data from 55 sample plots was used to test the validity of the biomass prediction model obtained with the training data. As shown in Figure 7, the model obtained with the training data could explain $54 \%$ variation of the biomass $\left(\mathrm{R}^{2}=0.54\right.$, $\left.\mathrm{RMSE}=34.09 \mathrm{Mg} \cdot \mathrm{ha}^{-1}\right)$.

\section{Conclusion}

Forest structural characteristics such as diameter at breast height, tree height, basal area, and above ground biomass were quantified by conducting field measurements in a tropical forest in Vietnam. The sensitivity of the structural characteristics to the polarizations of ALOS-2 SAR data, and to the season of the acquisition of the SAR data was analyzed. The regression analysis showed that horizontal structural parameter (basal area) was closely related to the SAR data than the vertical structure (tree height). However, combination of both the horizontal and vertical parameter as above ground biomass showed moderate sensitivity to the SAR data. Strong dependence of the estimation of biomass with the polarization and season of SAR data was found. Above ground biomass did not correlate with the rainy season HV polarization data as highly as the dry season $\mathrm{HV}$ polarization data. The combination of the $\mathrm{HH}, \mathrm{HV}$, and $\mathrm{HH} / \mathrm{HV}$ channels by multiple linear regression did not improve the estimates of the biomass than using $\mathrm{HV}$ channel independently since the $\mathrm{HH}$ and $\mathrm{HH} / \mathrm{HV}$ variables were not statistically significant (p-value $>0.05$ ). Therefore, this research concluded that the choice of right season in which SAR data is acquired is an important consideration for satellite based estimates of the forest structure. In tropical forests where the dry and rainy season are well-defined as in the case of our study area, the rainy season with frequent and plenty of rainfall and cloudy sky keeps the forest canopy wet and humid. Since the SAR backscattering intensity is highly sensitive to the surface moisture, the SAR data acquired in the rainy season is not sensitive to the forest biomass. The validation of the linear regression model fitted with the dry season $\mathrm{HV}$ polarization provided explanation of $54 \%$ variation of the biomass. 
Table 5. Summary of the relationship between field-measured biomass and SAR data using multiple linear regression analysis based coefficient of determination $\left(\mathrm{R}^{2}\right)$ and $\mathrm{p}$-value.

\begin{tabular}{cccc}
\hline \multirow{2}{*}{ Seasons } & & \multicolumn{2}{c}{$\mathbf{R}^{2}$ (p-value) with AGB } \\
\cline { 2 - 4 } & HV & HH & HH/HV \\
\hline Dry season & $0.58(0.000)$ & $0.58(0.21)$ & $0.58(0.19)$ \\
Rainy season & $0.36(0.000)$ & $0.36(0.17)$ & $0.36(0.17)$ \\
\hline
\end{tabular}



Figure 7. The validation result: above ground biomass versus dry season HV data. The 1:1 plot between the predicted and observed data are shown.

\section{Acknowledgements}

The authors are grateful to the project No. VAST 01. 03/15-16 from Vietnam Academy of Science and Technology (VAST) and Japan Society for the Promotion of Science (JSPS) for financial support to this research. We would like to thank JAXA for sharing ALOS-2 SAR data for this study in the frame work of ALOS Research program, PI No. 1172.

\section{References}

[1] Brown, S. (1997) Estimating Biomass and Biomass Change of Tropical Forests: A Primer (Vol. 134). Food \& Agriculture Org.

[2] IPCC (2006) Chapter 4: Forest Land. In: Eggleston, S., Buendia, L., Miwa, K., Ngara, T. and Tanabe, K., Eds., Guidelines for National Greenhouse Gas Inventories. Volume 4: Agriculture, Forestry and Other Land Use, IPCC, 9-12.

[3] Gibbs, H.K., Brown, S., Niles, J.O. and Foley, J.A. (2007) Monitoring and Estimating Tropical Forest Carbon Stocks: Making REDD a Reality. Environmental Research Letters, 2, 4. http://dx.doi.org/10.1088/1748-9326/2/4/045023

[4] Angelsen, A., et al. (2008) Moving ahead with REDD: Issues, Options and Implications. CIFOR. 143 p.

[5] FAO (2010) Global Forest Resources Assessment 2010-Main Report. FAO Forestry Paper 163, Rome, 378 p.

[6] D’Annunzio, R., Lindquist, E. and MacDicken, K.G. (2014) Global Forest Land Use Change from 1990 to 2010 : An Update to a Global Remote Sensing Survey of Forests. Food and Agriculture Organization of the United Nations. Report from FAO and European Commission Joint Research Centre, 6 p.

[7] Busch, J. and Engelmann, J. (2015) The Future of Forests: Emissions from Tropical Deforestation with and without a Carbon Price, 2016-2050. CGD Working Paper 411. Center for Global Development, Washington DC, 42 p. http://www.cgdev.org/publication/future-forests

[8] Stone, S. and León, Ch.M. (2011) Climate Change \& the Role of Forests. A Community Manual. Conservation International, Arlington.

[9] Way, A.D. and Pearcy, W.R. (2012) Sunflecks in Trees and Forests: From Photosynthetic Physiology to Global 
Change Biology. Tree Physiology, 32, 1066-1081. http://dx.doi.org/10.1093/treephys/tps064

[10] UN-REDD Vietnam (2012) Guidelines on Destructive Measurement for Forest Biomass Estimation. UN-REDD Vietnam Programme, $35 \mathrm{p}$.

[11] Ripple, W.J., Wang, S., Isaacson, D.L. and Paine, D.P. (1991) A Preliminary Comparison of Landsat Thematic Mapper and SPOT-l HRV Multispectral Data for Estimating Coniferous Forest Volume. International Journal of Remote Sensing, 12, 1971-1977. http://dx.doi.org/10.1080/01431169108955230

[12] Vincent, M.A. and Saatchi, S.S. (1999) Comparison of Remote Sensing Techniques for Measuring Carbon Sequestration. JPL Jet Propulsion Laboratory, California Institute of Technology.

[13] Foody, G.M., Boyd, D.S. and Cutler, M.E. (2003) Predictive Relations of Tropical Forest Biomass from Landsat TM Data and Their Transferability between Regions. Remote Sensing of Environment, 85, 463-474. http://dx.doi.org/10.1016/S0034-4257(03)00039-7

[14] Gonzalez, P., Asner, G.P., Battles, J.J., Lefsky, M.A., Waring, K.M. and Palace, M. (2010) Forest Carbon Densities and Uncertainties from Lidar, QuickBird, and Field Measurements in California. Remote Sensing of Environment, 114, 1561-1575. http://dx.doi.org/10.1016/j.rse.2010.02.011

[15] Chopping, M., Schaaf, C.B., Zhao, F., Wang, Z., Nolin, A.W., Moisen, G.G. and Bull, M. (2011) Forest Structure and Aboveground Biomass in the Southwestern United States from MODIS and MISR. Remote Sensing of Environment, 115, 2943-2953. http://dx.doi.org/10.1016/j.rse.2010.08.031

[16] Sharma, R.C., Kajiwara, K. and Honda, Y. (2013) Estimation of Forest Canopy Structural Parameters Using Kernel-Driven Bi-Directional Reflectance Model Based Multi-Angular Vegetation Indices. ISPRS Journal of Photogrammetry and Remote Sensing, 78, 50-57. http://dx.doi.org/10.1016/j.isprsjprs.2012.12.006

[17] Drake, J.B., Dubayah, R.O., Knox, R.G., Clark, D.B. and Blair, J.B. (2002) Sensitivity of Large-Footprint Lidar to Canopy Structure and Biomass in a Neotropical Rainforest. Remote Sensing of Environment, 81, 378-392. http://dx.doi.org/10.1016/S0034-4257(02)00013-5

[18] Lefsky, A.M., Warren, B.C., Geoffrey, G.P. and Harding, J.D. (2002) Lidar Remote Sensing for Ecosystem Studies. BioScience, 52, 19-30. http://dx.doi.org/10.1641/0006-3568(2002)052[0019:Irsfes]2.0.co;2

[19] Popescu, S.C., Wynne, R.H. and Nelson, R.F. (2005) Measuring Individual Tree Crown Diameter with Lidar and Assessing Its Influence on Estimating Forest Volume and Biomass. Canadian Journal of Remote Sensing, 29, 564-577. http://dx.doi.org/10.5589/m03-027

[20] Bortolot, Z.J. and Wynne, R.H. (2005) Estimating Forest Biomass Using Small Footprint LiDAR Data: An Individual Tree-Based Approach that Incorporates Training Data. ISPRS Journal of Photogrammetry and Remote Sensing, 59, 342-360. http://dx.doi.org/10.1016/j.isprsjprs.2005.07.001

[21] Beets, P.N., Reutebuch, S., Kimberley, M.O., Oliver, G.R., Pearce, S.H. and McGaughey, R.J. (2011) Leaf Area Index, Biomass Carbon and Growth Rate of Radiata Pine Genetic Types and Relationships with LiDAR. Forests, 2, 637-659. http://dx.doi.org/10.3390/f2030637

[22] Moskal, L.M. and Zheng, G. (2011) Retrieving Forest Inventory Variables with Terrestrial Laser Scanning (TLS) in Urban Heterogeneous Forest. Remote Sensing, 4, 1-20. http://dx.doi.org/10.3390/rs4010001

[23] Kankare, V., Vastaranta, M., Holopainen, M., Räty, M., Yu, X., Hyyppä, J., Hyyppa, H., Alho, P. and Viitala, R. (2013) Retrieval of Forest Aboveground Biomass and Stem Volume with Airborne Scanning LiDAR. Remote Sensing, 5, 2257-2274. http://dx.doi.org/10.3390/rs5052257

[24] Sheridan, R.D., Popescu, S.C., Gatziolis, D., Morgan, C.L. and Ku, N.W. (2014) Modeling Forest Aboveground Biomass and Volume Using Airborne LiDAR Metrics and Forest Inventory and Analysis Data in the Pacific Northwest. Remote Sensing, 7, 229-255. http://dx.doi.org/10.3390/rs70100229

[25] Hansen, E.H., Gobakken, T., Bollandsås, O.M., Zahabu, E. and Næsset, E. (2015) Modeling Aboveground Biomass in Dense Tropical Submontane Rainforest Using Airborne Laser Scanner Data. Remote Sensing, 7, 788-807. http://dx.doi.org/10.3390/rs70100788

[26] Ulaby, F.T., Moore, R.K. and Fung, A.K. (1981) Microwave Remote Sensing: Active and Passive. Vol. 1, AddisonWesley, Reading, $456 \mathrm{p}$.

[27] Wu, S.T. (1987) Potential Application of Multipolarization SAR for Pine-Plantation Biomass Estimation. IEEE Transactions on Geoscience and Remote Sensing, 25, 403-409. http://dx.doi.org/10.1109/TGRS.1987.289811

[28] Le Toan, T., Beaudoin, A., Riom, J. and Guyon, D. (1992) Relating Forest Biomass to SAR Data. IEEE Transactions on Geoscience and Remote Sensing, 30, 403-411. http://dx.doi.org/10.1109/36.134089

[29] Dobson, M.C., Ulaby, F.T., Pierce, L.E., Sharik, T.L., Bergen, K.M., Kellndorfer, J. and Sarabandi, K. (1995) Estimation of Forest Biophysical Characteristics in Northern Michigan with SIR-C/X-SAR. IEEE Transactions on Geoscience and Remote Sensing, 33, 877-895. http://dx.doi.org/10.1109/36.406674 
[30] Luckman, A., Baker, J., Kuplich, M.T., Yanasse, F.C.C. and Frery, C.A. (1997) A Study of the Relationship between Radar Backscatter and Regenerating Tropical Forest Biomass for Spaceborne SAR Instruments. Remote Sensing of Environment, 60, 1-13. http://dx.doi.org/10.1016/S0034-4257(96)00121-6

[31] Jensen, J.R. (2000) Remote Sensing of the Environment: An Earth Resource Perspective. 3rd Indian Reprint, Pearson Education (Singapore) Pte. Ltd., Indian Branch, Delhi, 557 p.

[32] Le Toan, T., Quegan, S., Davidson, M.W.J., Balzter, H., Paillou, P., Papathanassiou, K., Plummer, S., Rocca, F., Shugart, H. and Ulander, L. (2011) The BIOMASS Mission: Mapping Global Forest Biomass to Better Understand the Terrestrial Carbon Cycle. Remote Sensing of Environment, 115, 2850-2860. http://dx.doi.org/10.1016/j.rse.2011.03.020

[33] Sandberg, G., Ulander, L.M., Fransson, J.E.S., Holmgren, J. and Le Toan, T. (2011) L- and P-Band Backscatter Intensity for Biomass Retrieval in Hemiboreal Forest. Remote Sensing of Environment, 115, 2874-2886. http://dx.doi.org/10.1016/j.rse.2010.03.018

[34] Ghasemi, N., Sahebi, M.R. and Mohammadzadeh, A. (2011) A Review on Biomass Estimation Methods Using Synthetic Aperture Radar Data. International Journal of Geomatics and Geosciences, 1, 776-788.

[35] Hajnsek, I., Kugler, F., Lee, S.K. and Papathanassiou, K.P. (2009) Tropical-Forest-Parameter Estimation by Means of Pol-InSAR: The INDREX-II Campaign. IEEE Transactions on Geoscience and Remote Sensing, 47, 481-493. http://dx.doi.org/10.1109/TGRS.2008.2009437

[36] Brolly, M. and Woodhouse, I.H. (2014) Long Wavelength SAR Backscatter Modelling Trends as a Consequence of the Emergent Properties of Tree Populations. Remote Sensing, 6, 7081-7109. http://dx.doi.org/10.3390/rs6087081

[37] Santos, J.R., Lacruz, M.P., Araujo, L.S. and Keil, M. (2010) Savanna and Tropical Rainforest Biomass Estimation and Spatialization Using JERS-1 Data. International Journal of Remote Sensing, 23, 1217-1229. http://dx.doi.org/10.1080/01431160110092867

[38] Morel, C.A., Saatchi, S.S., Malhi, Y., Berry, J.N., Banin, L., Burslem, D., Nilus, R. and Ong, C.R. (2011) Estimating Aboveground Biomass in Forest and Oil Palm Plantation in Sabah, Malaysian Borneo Using ALOS PALSAR Data. Forest Ecology and Management, 262, 1786-1798. http://dx.doi.org/10.1016/j.foreco.2011.07.008

[39] Englhart, S., Keuck, V. and Siegert, F. (2011) Aboveground Biomass Retrieval in Tropical Forests-The Potential of Combined X- and L-Band SAR Data Use. Remote Sensing of Environment, 115, 1260-1271. http://dx.doi.org/10.1016/j.rse.2011.01.008

[40] Carreiras, J.M.B., Melo, J.B. and Vasconcelos, M.J. (2013) Estimating the Above-Ground Biomass in Miombo Savanna Woodlands (Mozambique, East Africa) Using L-Band Synthetic Aperture Radar Data. Remote Sensing, 5, $1524-$ 1548. http://dx.doi.org/10.3390/rs5041524

[41] Balzter, H., Rowland, C.S. and Saich, P. (2007) Forest Canopy Height and Carbon Estimation at Monks Wood National Nature Reserve, UK, Using Dual-Wavelength SAR Interferometry. Remote Sensing of Environment, 108, 224-239. http://dx.doi.org/10.1016/j.rse.2006.11.014

[42] Champion, I., Dubois-Fernandez, P., Guyon, D. and Cottrel, M. (2008) Radar SAR Images Texture as a Function of Forest Stand Age. International Journal of Remote Sensing, 29, 1795-1800. http://dx.doi.org/10.1080/01431160701730128

[43] Cartus, O., Santoro, M. and Kellndorfer, J. (2012) Mapping Forest Aboveground Biomass in the Northeastern United States with ALOS PALSAR Dual-Polarization L-Band. Remote Sensing of Environment, 124, 466-478. http://dx.doi.org/10.1016/j.rse.2012.05.029

[44] Mermoz, S., Réjou-Méchain, M., Villard, L., Le Toan, T., Rossi, V. and Gourlet-Fleury, S. (2015) Decrease of L-Band SAR Backscatter with Biomass of Dense Forests. Remote Sensing of Environment, 159, 307-317. http://dx.doi.org/10.1016/j.rse.2014.12.019

[45] Richards, J., Sun, G.Q. and Simonett, D.S. (1987) L-Band Radar Backscatter Modeling of Forest Stands. IEEE Transactions on Geoscience and Remote Sensing, 25, 487-498.http://dx.doi.org/10.1109/TGRS.1987.289861

[46] Mika, K., Ulla, P., Karila, K. and Juha, H. (2009) Forest Biomass Estimation Using ALOS PALSAR Images in Challenging Natural Forest Area in Finland. Proceedings of ALOS PI 2008 Symposium, Island of Rhodes, 3-7 November 2008, ESA Special Publication SP-664.

[47] Lucas, R., Armston, J., Fairfax, R., Fensham, R., Accad, A., Carreiras, J. and Shimada, M. (2010) An Evaluation of the ALOS PALSAR L-Band Backscatter-Above Ground Biomass Relationship Queensland, Australia: Impacts of Surface Moisture Condition and Vegetation Structure. IEEE Journal of Selected Topics in Applied Earth Observations and Remote Sensing, 3, 576-593. http://dx.doi.org/10.1109/JSTARS.2010.2086436

[48] Iizuka, K. and Tateishi, R. (2015) Estimation of $\mathrm{CO}_{2}$ Sequestration by the Forests in Japan by Discriminating Precise Tree Age Category Using Remote Sensing Techniques. Remote Sensing, 7, 15082-15113. http://dx.doi.org/10.3390/rs71115082

[49] Poolla, S.B. (2013) Polarimetric Scattering Model for Biophysical Characterization of Multilayer Vegetation Using 
Space Borne PolSAR Data. Facultyof Geoinformation Science and Earth Observation, University of Twente.

[50] Lo, C.P. (1988) Applications of Imaging Radar to Land Use and Land Cover Mapping. In: Henderson, F.M. and Lewis, A.J., Eds., Manual of Remote Sensing, Vol. 2, 3rd Edition, Wiley, USA, 896 p.

[51] Touzi, R., Deschamps, A. and Rother, G. (2007) Wetland Characterization Using Polarimetric RADARSAT-2 Capability. Canadian Journal of Remote Sensing, 33, S56-S67. http://dx.doi.org/10.5589/m07-047

[52] Ordonez, F.Y., Ruiz, S.J. and Leblon, B. (2008) Forest Inventory Using Optical and Radar Remote Sensing. In: Jedlovec, G., Ed., Advances in Geoscience and Remote Sensing, InTech, Rijeka.

[53] Le Toan, T., Mermoz, S., Bouvet, A. and Villard, L. (2013) K\&C Phase 3. Forest Cover Change and Biomass Mapping. K\&C Initiative, Report on an International Science Collaboration Led by JAXA.

[54] Ranson, K.J. and Sun, G. (1994) Mapping Biomass of a Northern Forest Using Multifrequency SAR Data. IEEE Transactions on Geoscience and Remote Sensing, 32, 388-396. http://dx.doi.org/10.1109/36.295053

[55] Ranson, K.J. and Sun, G. (1997) Effect of Environmental Temperatures on SAR Forest Biomass Estimates. 1997 International Geoscience and Remote Sensing Symposium, 4, 1722-1724. http://dx.doi.org/10.1109/igarss.1997.609043

[56] Joseph, T.A., Van der Velde, R., O’Neill, E.P., Lang, R. and Gish, T. (2010) Effects of Corn on C- and L-Band Radar Backscatter: A Correction Method for Soil Moisture Retrieval. Remote Sensing of Environment, 114, 2417-2430. http://dx.doi.org/10.1016/j.rse.2010.05.017

[57] Shi, J., Wang, J., Hsu, A.Y., O’Neill, P.E. and Engman, E.T. (1997) Estimation of Bare Surface Soil Moisture and Surface Roughness Parameter Using L-Band SAR Image Data. IEEE Transactions on Geoscience and Remote Sensing, 35, 1254-1266. http://dx.doi.org/10.1109/36.628792

[58] Bindlish, R. and Barros, A.P. (2001) Parameterization of Vegetation Backscatter in Radar-Based, Soil Moisture Estimation. Remote Sensing of Environment, 76, 130-137. http://dx.doi.org/10.1016/S0034-4257(00)00200-5

[59] Baghdadi, N., Holah, N. and Zribi, M. (2006) Calibration of the Integral Equation Model for SAR Data in C-Band and $\mathrm{HH}$ and VV Polarizations. International Journal of Remote Sensing, 27, 805-816. http://dx.doi.org/10.1080/01431160500212278

[60] Kasischke, E.S., Bourgeau-Chavez, L.L., Rober, A.R., Wyatt, K.H., Waddington, J.M. and Turetsky, M.R. (2009) Effects of Soil Moisture and Water Depth on ERS SAR Back Scatter Measurements from an Alaskan Wetland Complex. Remote Sensing of Environment, 113, 1868-1873. http://dx.doi.org/10.1016/j.rse.2009.04.006

[61] Huang, W., Sun, G., Zhang, Z. and Ni, W. (2015) Sensitivity of Multi-Source SAR Backscatter to Changes of Forest Aboveground Biomass. Remote Sensing, 7, 9587-9609. http://dx.doi.org/10.3390/rs70809587

[62] Gharechelou, S., Tateishi, R., Sharma, R.C. and Johnson, B.A. (2016) Soil Moisture Mapping in an Arid Area Using a Land Unit Area (LUA) Sampling Approach and Geostatistical Interpolation Techniques. ISPRS International Journal of Geo-Information, 5, 35. http://dx.doi.org/10.3390/ijgi5030035

[63] Panciera, R., Tanase, M., Lowell, K. and Walker, J.P. (2014) Evaluation of IEM, Dubois, and Oh Radar Backscatter Models Using Airborne L-Band SAR. IEEE Transactions on Geoscience and Remote Sensing, 52, 4966-4979. http://dx.doi.org/10.1109/TGRS.2013.2286203

[64] Kim, C. (2012) Quantitative Analysis of Relationship between ALOS PALSAR Backscatter and Forest Stand Volume. Journal of Marine Science and Technology, 20, 624-628.

[65] Park, S.E., Moon, W.M. and Pottier, E. (2012) Assessment of Scattering Mechanism of Polarimetric SAR Signal from Mountainous Forest Areas. IEEE Transactions on Geoscience and Remote Sensing, 50, 4711-4719. http://dx.doi.org/10.1109/TGRS.2012.2194153

[66] Wang, C. and Qi, J. (2008) Biophysical Estimation in Tropical Forests Using JERS-1 SAR and VNIR Imagery. II. Aboveground Woody Biomass. International Journal of Remote Sensing, 29, 6827-6849. http://dx.doi.org/10.1080/01431160802270123

[67] Lewis, S.L., Sonké, B., Sunderland, T., Begne, S.K., Lopez-Gonzalez, G., Van Der Heijden, G.M., Simo, M., et al. (2013) Above-Ground Biomass and Structure of 260 African Tropical Forests. Philosophical Transactions of the Royal Society B: BioSciences, 368, 20120295.

[68] Champion, I., Da Costa, P., Godineau, A., Villard, L., Dubois-Fernandez, P. and Le Toan, T. (2013) Canopy Structure Effect on SAR Image Texture versus Forest Biomass Relationships. EARSeL eProceedings, 12, 25-32. http://www.eproceedings.org/static/vol12_1/12_1_champion1.pdf

[69] Nghia Nguyen, T., Anh Nguyen, D., Vu Anh, T., Nguyen, T.K.T. and Thi Nguyen, D. (2008) Update Information of Flora and Plant's Resources of Yok Don National Park, Daclak Province in 2008.

[70] UNESCO (1973) International Classification and Mapping of Vegetation. United Nations Educational, Scientific and Cultural Organization, Paris, 102 p. 
[71] Van Thai, T. (1978) Chapter IV: Classification of Tropical Forest Vegetation in Vietnam; Chapter V: The Vegetation Types and Dominance Species on Forest Land in Vietnam. In: The Vegetation Cover in Vietnam, 2nd Edition, Science and Technics Publishing House, Hanoi, 276 p.

[72] Van Thai, T. (1998) Chapter IV: The Types of Tropical Forest Vegetation in Vietnam. In: The Tropical Forest Ecosystem in Vietnam, Science and Technics Publishing House, Hanoi, 291 p.

[73] Ngoc Phung, L., Nguyen Phan, H., Van Trieu, H., Nghia Nguyen, T. and Tran Le, Ch. (2006) Natural Forest Ecosystems Viet Nam. Ministry of Agriculture and Rural Development of Vietnam (MARD), 95 p.

[74] MARD (2010) Soil Map in Highlands’s Region in 2010, Scale 1:250.000. National Institute for Agricultural Planning-Remote Sensing Center, Ministry of Agriculture and Rural Development of Vietnam (MARD).

[75] Xuan Nguyen, C., Quy Ha, Q., The Luu, A. and Viet Nguyen, L. (2009) Report on Conservation Planning and Sustainable Development of Yok Don National Park in 2010-2020. Ministry of Agriculture and Rural Development (MARD), 140 p.

[76] JAXA (2014) ALOS-2/Calibration Result of JAXA Standard Products. Japan Aerospace Exploration Agency, Earth Observation Research Center. http://www.eorc.jaxa.jp/ALOS-2/en/calval/calval_index.htm

[77] MONRE (2014, 2015) Survey Data Base of Hydrometeorology Sector, Has Been Archived at Center of National Hydro-Meteorological Service. Ministry of Natural Resources and Environment, Vietnam.

[78] Van Vo, H., Van Tran, H. and Ngoc Pham, B. (2006) Handbook for Vietnam Forest Inventory. Ministry of Agriculture and Rural Development of Vietnam (MARD), 95 p.

[79] Vu Tan, P., Viet Nguyen, X., Trieu Thinh, D., et al. (2012) PART B-6. Tree Allometric Equations in Evergreen Broadleaf, Deciduous, and Bamboo Forest in Central Highland Region, Vietnam. UN-REDD Vietnam Programme, 96 p.

[80] Hoang Pham, H. (2003) Flora of Viet Nam. Vol. 1, 2, 3, Young Publishing House, Ho Chi Minh City.

[81] IPCC (2003) Good Practice Guidance for Land Use, Land-Use Change and Forestry. IPCC National Greenhouse Gas Inventories Programme Technical Support Unit, Printed in Japan. 